\title{
Effect of Innovation to the Success of Female Entrepreneurs
}

\author{
Kim Piew Lai, Robert Jeyakumar Nathan, Khong Sin Tan, and Boon Bun Chan \\ Multimedia University, Melaka, Malaysia
}

\begin{abstract}
This ongoing study investigates the characteristics of innovation and its influence as a success factor for female entrepreneurs in Malaysia. It starts by presenting an extensive review of literatures in the area of entrepreneurship, particularly focusing on women entrepreneurs. Purposive sampling, namely snowball sampling method is used to collect data from small and medium enterprises owned by female entrepreneurs in Malaysia. The study examines the associations among Innovation Conviction (ICN), Innovation Mindset (IMT), Innovation Creed (ICD) and the Need for Achievement (NFA). Descriptive and inferential statistics were carried out to the gathered data and presented in this paper. Findings indicate that ICN, ICT and IMT are positively correlated with the Need for Achievement among female entrepreneurs in Malaysia.
\end{abstract}

Keywords: female entrepreneur, innovation, need for achievement

\section{Introduction}

According to the Bureau of Census, businesses owned by female entrepreneurs contributed only to a small percentage of $4.6 \%$ in 1972 , but has since grown tremendously in number. Bureau of Labor USA stated that selfemployed women projected an increased figure of 3.5 million in 1984 from 1.5 million in 1972 (Hisrich and Brush, 1986). By 1999, there were 9.1 million women-owned businesses who employed 27.5 million workers with profits approximately \$3.6 trillion. From 1997 to 2002, women formed new businesses at twice the national rate. Based on Center for Women's Business Research, by 2003 women entrepreneurs had been recognized as a main driver in the U.S. economy. In addition, numerous collaborations showed that female-owned businesses were gradually becoming an important factor for the global economy (www.nfwbo.org, 2009). Normah (2006), as reported in National Statistics Conference, Malaysia cited that female participation in businesses is showing a positive trend and growing throughout the years.

"The participation of women in small and medium enterprises in 2003 is $1,121,687$ or $36.8 \%$ of total employment. A proxy for women entrepreneurs obtained from the Census results i.e. working proprietors and active business partners, indicate 30.3\%." (Normah, 2006)

Although participation of female entrepreneurs and female-owned businesses has gradually increasing from $18.0 \%$ in 2000 to $27.8 \%$ in 2003 (Normah, 2006), there still exists barriers which prevent women from entering the market, such as fear of failure, lack of media coverage on entrepreneurships and incompetency of starting a new business. Less attention has been given to reduce the 
barriers that stereotyping women in entrepreneurial activities. Malaysia is a developing and progressing country where women are receiving equal education opportunities with man. However, the older generation still find it unusual when a business is operated by a woman, or when a housewife becomes a leader of an organization.

There are a number of factors that contribute to the success of a female entrepreneur in the face of challenges that she faces to succeed such as self confident personalities, willingness to take risk, past working experience and innovative ideas. Therefore, the aim of this study is to investigate contribution of innovation to the success in businesses operated by female entrepreneurs in Malaysia.

\section{Literature Review}

Entrepreneurship and Female Entrepreneurs

Entrepreneurship is the creation of new values by entrepreneurs through the devotion of their time and effort, assuming the accompanying financial, psychic, social risks, and getting the resulting rewards in monetary, personal satisfaction and independence (Hisrich, 2002). The review of the literature shows several different definitions for entrepreneur, but few definitions stand out. An entrepreneur can be defined as a person who creates a new business in the dimensions of uncertainty for gaining growth and monetary profits by recognizing opportunities and constructing the required resources (Zimerer and Searborough, 2002).

Joseph Schumpeter commented that successful entrepreneurs should be creative enough to spark new profound ideas and new methods of utilizing resources that can be viewed differently (Ronstadt, 1988; Shefsky, 1994). A female entrepreneur is a woman who has the inner-drive and self-initiative attitude to begin her own business (Starr and Yudkin, 1996). Lavoie described female entrepreneur as the leader in any business and must take the first attempt to launch new business venture, manage day to day risks, handle financial, coordinate administrative, hold social responsibilities, and take charge of its day-to-day management (Moore and Buttner, 1997).

A growing number of people are looking at entrepreneurship with positive attitude (Wennekers, 2006). Silver (1983) noted that entrepreneurs begin to start their own ventures because current careers are inadequate in providing them enough justifications and satisfaction to excel. Some organizations react passively during the changing scenario such as recession, inflation and economic down-turn that deliberately compel many employees pursue other alternative forms of jobs. Mergers, acquisitions, downsizing, and decentralization, have retrenched a high numbers of whitecollar, skilled and professional workers onto the job market. Some of these dislocated professionals start their new businesses based on new ideas, targeting new market segments, offering new products and services, etc.

Today, more women are trying to become the trendsetters by deviating from the traditional, gender-specific roles and investing into the business ventures. Arfken et. al. (2004), showed a growing number of women-owned businesses in USA. Currently, women represent about half of the U. S. labour force and hold $42.7 \%$ of the entry level and midlevel management positions (U.S. Department of Labor, 1996). However the statistics indicate that the percentages of women in corporate ladders are still at infancy stage and make up to less than three percent in the U.S.A. (Catalyst, 2002).

Female entrepreneurs are becoming more important and prominent than before. Verheul et. al. (2006) pointed that, "Increasingly, female entrepreneurs are considered important for economic development." Globally, most of the women are self-employed, and was estimated that women are capable at owning and managing up to one third of all businesses in developed 
countries (McClelland et. al., 2005). An evidence to support this claim is found in Langowitz et. al. (2003) who stated "Womenfounded and owned firms represent a raising percentage of businesses and business revenues in the United States. In year 2000, $38 \%$ of businesses in the United States were owned by women" (Centre for Women's Business Research, 2001).

McClelland et. al. (2005) have further confirmed that female entrepreneurs' activities could contribute significantly to their communities and economies, in the developed and developing countries. Business owners tend to assume management roles while maintaining a high level of control and overseeing of the business operations. With such influences, these business owners could have some major impact on the growth orientations and performance of their businesses (Kangasharju, 2000).

Hornaday and Bunker (1970) studied the characteristics of successful entrepreneurs. They noted that successful entrepreneurs viewed highly on the need for achievement, self-reliance, being competitive, self-initiative, self-confidence, being versatile, perseverance, resilience, being innovative and maintaining a good physical health.

Casson (1982a, 1982b) noticed that the typical characteristics for entrepreneurs to succeed are related to their capabilities to take risks, to innovate, to obtain knowledge of how the market functioning, to possess manufacturing know-how, to learn marketing skills, to practice good business management skills, and to have the ability to co-operate. Carland and Carland (1992) concluded that to sustain any business venture, entrepreneurs need to portray the roles as risk takers, high achievers, innovators, and problem solvers.

\section{Need for achievement}

McClelland et. al. (2005) believed that the need for achievement is the main motivator for any entrepreneurs to excel. Lee (1996) quoted "This need to achieve excellence motivates individuals to overcome obstacles, to exercise power, to strive to do something".

The need for achievement can be defined as a person's deep desire for excellence or to succeed in competitive environments. In addition, the need for achievement can be classified as the psychological variables in which often been recalled to justify the individual's differences in its tendency toward the drive of success in life. Of all the identified entrepreneurial needs in the past literatures, the need for achievement stands out consistently as the principal motive for entrepreneurial success. Such need facilitates individual to overcome unforeseen obstacles whether willingly or unwillingly inherent in entrepreneurial activities (Lee, 1996). Prominent entrepreneurs with the strong need for achievement are more likely to persist in their day to day activities, even though it may be challenging (March, 1991).

\section{Innovation}

Innovative idea can be classified as a need that has not been adequately fulfilled. An innovative idea may derive from areas such as own imagination, problem solving experience, learn from dissatisfied customers, related works, past-time hobbies, demographic changes in society, or just luck (Davis and Long, 1999).

Schumpeter is highly regarded as an outstanding researcher who successfully tied entrepreneurship to innovation. He linked innovation with the need for entrepreneurs to innovate new services, qualities, processes, market segments, source of supplies, or industries (Baumol, 1993). Later, he reconstructed several new categories in which these categories can be benchmark to distinguish business organizations from innovative entrepreneurships clearly. Casson (1982a) ranked an organization based on the substantial level of innovation such as high and low degree of innovative entrepreneurships. Wickham (2004), however added three different dimensions i.e. innovation, growth potential and strategic objective that need to be viewed as a 
complementary along for differentiating small businesses from entrepreneurial ventures.

Brambilla (2009) looked at how firms can be grown when expanding their product varieties in a model where product development was induced with fixed costs. Heavy investment which initially required for improving innovation had caused an irrevocably hidden wall that blocked new entrepreneurs and industries from joining the market (Hummels and Lugovskyy, 2005).

In this research, innovation is re-classified further into three main components that made up of innovation factor in which the researcher believes these three components may relate significantly and differently to the need for achievement. The components of innovation comprised Innovation Conviction (ICN), Innovation Mindset (IMT) and Innovation Creed (ICD). The components of innovation were adopted from Kuczmarski's (1996) perspectives on innovation as the leadership strategy for the competitive edge.

Innovation Conviction (ICN) is regarded as an attitude which relatively materializing its sincerity in conveying commitments. As these groups of so called entrepreneurs tend to make, change and amend statements easily through company's mission, they will be viewed as lack of sincerity by their employees quickly. This has caused many of their employees pass on negative remarks on their superior such as unreasonable lip service or do not walk the talk. Some would even question their employer for the so called company's direction through mission statements which eventually when put to actual work, it is not aligned as directed by their lady bosses. So, talk is easier than actually doing it. But to identify entrepreneur's sincerity in delivering commitments, entrepreneur's level of innovation conviction need to be measured. Therefore ICN is measuring their determinacy of readiness to accept innovation (Kuczmarski, 1996).
The conviction to innovate is essential for success, as it will increase the level of innovation that an entrepreneur introduces into her business. As an entrepreneur, conviction alone is insufficient if not accompanies by motivation that results in action. What will happen if the entrepreneurs have the conviction but lack the motivation and interests in innovation? Some would end up in foregoing their desire to do business altogether, while some discard innovation strategy from their business strategies. When she believes in innovation as the success factor, she needs to evoke her personal conviction through innovation creed (ICD). As stipulated by Kuczmarski (1996), entrepreneurs need to uphold their personal conviction strongly through sufficient insights (beliefs) about innovation. Based on this explanation, Innovation Creed (ICD) is defined as female entrepreneur's belief and motivation for increased innovation.

Innovation Mindset (IMT) is related to attitude, a positive attitude that drives businesses to envision beyond the present and projects future direction. As claimed by Kuczmarski (1996), if an organization has the capability to change their employees' behaviour (through changes in attitudes) and adopts innovation positively, success is just a foot step away. However to change employees' behaviours, a positive corporate culture is needed to lead them to think more creatively through drastic changes in strategies, product features and service characteristics. As positive behaviour takes positive effort to develop, it is not impossible to achieve it. Positive mindset in one entrepreneur will lead to other employees' positive behaviours. Positive mindset can be learned and eventually passed on to the employees through proper training and sharing. Only through innovation mindset, entrepreneurs will be able to win the respect of their employees and customers (Kuczmarski, 1996). 
The relationship between entrepreneur and innovation

Entrepreneurs do not innovate merely to seek for opportunities. Often its about identifying a "forgotten" area of business, opportunities or niche area of business where customers' needs are not yet adequately met. These opportunities are those that large firms either ignore, seek not to produce, or cannot physically create or manufacture. Entrepreneurship in itself does not guarantee innovation. However, it is the willingness to venture, be nonconformist and constantly look for new solutions which large companies often fail to do, that allows innovation to thrive, especially in small and medium sized businesses.

For new start-ups of small venture firms, innovative entrepreneurs are important as they play the roles of a main driver that keep the venture grow and become profitable. It is believed that new business start-ups and innovations are highly related.

Being independent and often individualistic are important personalities for entrepreneurs to succeed. Individualism is highly related to innovation through entrepreneurship and the creation of small enterprises. Through the independence of the entrepreneur, the entrepreneurial ventures may gain acceptance in a society.

The relationship between the need for achievement and innovation

Entrepreneurship is recognized by scholars as a micro driver of innovation and economic growth (Acs, 2006; Audretsch and Thurik, 2001; Audretsch et. al., 2006; Wennekers and Thurik, 1999). Porter (1985) stressed that innovation is an important and major factor determining the survival of any business today. Successful firms revived through innovation and new break-through, as innovation is the new way to disrupt and out play competitors. Hence, the entrepreneurs need to have the characteristics of innovative knowledge creation.
Entrepreneurs must also acquire the ability to innovate knowledge creatively. This exercise required the correct and balanced combination of characteristics and experiences associated with entrepreneurs. Although entrepreneurs preferred to behave individually rather then collectively, they need to capitalize on their individual skills and at the same time collectively utilize group resources to identify new business ventures; select and organize better enterprises and manage risks. To strive as a successful entrepreneur, working alone may not be enough. Creatively gathering various ideas and collaborations are identified as key for the survival of new enterprises.

Kiyonari et. al. (1971) stated that venture business focuses and engages intensively on company's creative researches and developments. Venture business can be distinguished by two main characteristics. The first characteristics requires entrepreneur to behave positively towards any new enterprises in which risk exists. Second characteristics is a must do innovation activities for entrepreneurs. Birch's (1987) findings revealed economic development and entrepreneurship are positively linked.

Heunks (1998) pointed out that the success of small and medium-sized enterprises depend heavily on innovation. Besides innovation, individual characteristics of entrepreneurs such as positive posture, ethical values and possess tertiary education have positive association with a company's innovation and originality.

From the review of literatures in the area of entrepreneurship and female business owners, this study believes that innovation is indeed an important characteristic because it influences entrepreneurial success. For enterprises to emerge and expand, factors such as learned talent, sophisticated technology and sufficient capital can be regarded as important capabilities. Besides, other elements that are required include the "know-how" and the ability to improve 
business or scientific knowledge. It is the ability to find and apply know-how in various areas that marks the differences between success and meritocracy. And this knowledge may be applicable to all business disciplines. Furthermore, the entrepreneurs should lead and drive innovation, and if society would like to generate innovation, a conducive environment is needed to allow entry and for facilitating the development of small new enterprises.

\section{Research Methods}

This section discusses the methodology of the study in collecting, analysing and presenting the research data. Hypotheses testing procedures are also discussed. A research framework called Innovation Adoption among Female Entrepreneur is developed. The research variables are identified through literature review and in particular from Kuczmarski's (1996) perspectives of innovation. Research hypotheses are constructed to test the relationship between the ICN, IMT, ICD and need for achievement (NFA) (Refer to Appendix A for the measures of each variable/construct). This section also discusses the procedures on data collection, development of the questionnaires, sampling procedure and data analysis techniques.

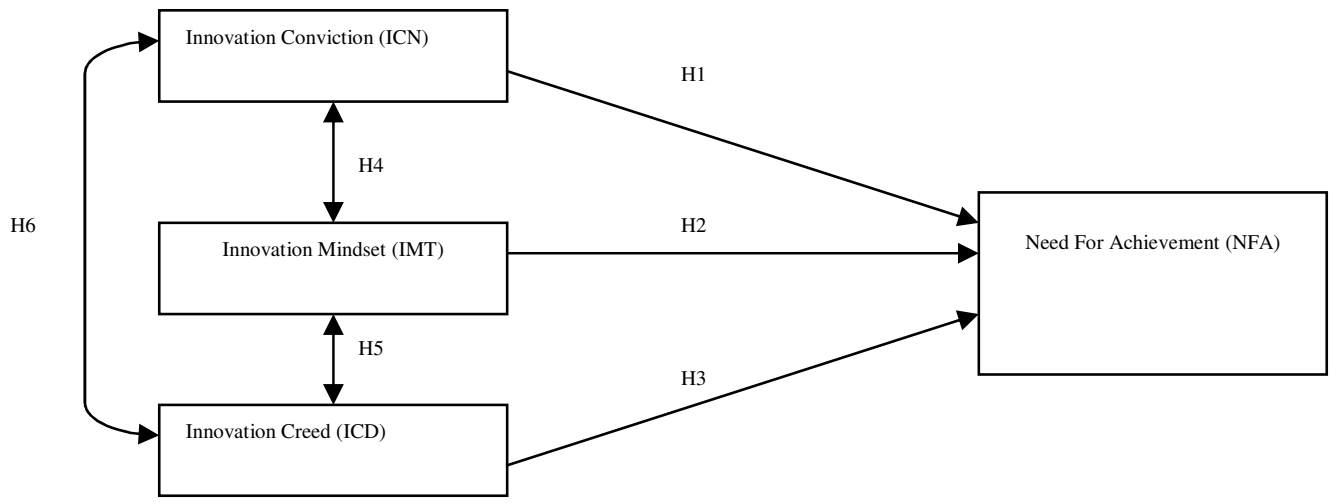

Figure 1: Research Framework

The dependent variable in this study is Need for Achievement (NFA); the independent variables are Innovation Mindset (IMN), Innovation Conviction (ICN) and Innovation Creed (ICD). The study would analyse the relationships between and among the dependent and independent variables of the study.

\section{Sampling and Data Collection}

A survey was conducted to collect primary data needed for this study. The questionnaire gathered respondents' information on demographics and types of industry they are in. Second section of the questionnaire measures the research variables through a five-point Likert scale ( $5=$ strongly agree to $1=$ strongly disagree).
Non-probably sampling method was used to collect the sample for this study i.e. Snowball sampling while trying to control for race of respondents. In Malaysia the major races include Malay, Chinese and Indians. The questionnaires were distributed to Malay, Chinese and Indian female entrepreneurs equally; to be filled and further circulated to other female entrepreneurs known to them. Most respondents came from Melaka and Johor (the Southern States of Malaysia) as the initial contacts of the respondents came from these states.

Most of the responses collected came from female entrepreneurs in small and medium enterprises (SME). Three hundred questionnaires were circulated for data 
collection of which only 78 replied. Filtration was done my mainly removing incomplete responses. After filtration, only 56 respondents (18.67 percent) correctly completed the questionnaires. As the initial response rate from mailed questionnaires was low, personal interviews were carried out in search for more data. Mailed questionnaire responses coupled with personal interviews yield 120 sample data ready for analysis. This sample size is deemed appropriate for further statistical analysis (Sekaran, 2002).

The data was analyzed using the SPSS (Statistical Package for the Social Sciences) version 16. Descriptive statistics and hypothesis testing using correlation analyses were carried out to analyse the association between and among the independent and dependent variables in study.

\section{Hypothesis Development}

Achievement or success refers to the aim for achievement. In this study, the female entrepreneurs' achievements refer to the business reaping profits without facing financial problems. A total of six hypotheses were developed to describe the relationships among the variables in the study. Based on the conceptual model of Innovation Adoption among Female Entrepreneurs (Figure 1), the study formulates the following hypotheses:

\section{H1: Innovation Conviction (ICN) has a significant association with Need for Achievement (NFA)}

As the conviction of female's entrepreneur is regarded as her attitude toward innovation. Some may take conviction lightly while others may do the opposite. If female entrepreneurs are not convicted to improve themselves through innovation, then how do they survive? So this hypothesis is designed to measure their readiness to innovate and succeed

H2: Innovation Mindset (IMT) has a significant association with Need for Achievement (NFA)

But before conviction, their mindset must be aligned. As mindset is a positive attitude that drives businesses, female entrepreneurs must develop positive behaviour that lead their employees creatively to create new strategies, product features and service characteristics. With positive attitude, female entrepreneurs can gain the rightful respects, which eventually lead them to successful businesses. Hence, it would be interesting to find out whether positive attitude can lead to innovation mindset and their need for success through $\mathrm{H} 2$.

H3: Innovation Creed (ICD) has a significant association with Need for Achievement (NFA)

Same goes to H3, as conviction is responsible for the success of female entrepreneurs by gradually increasing the level of readiness to accept innovation. However based on conviction alone is insufficient because female entrepreneurs required some push factor such as motivation to evoke their conviction toward innovation and success. As claimed by Kuczmarski (1996), conviction can be enhanced through beliefs. Therefore the researcher assumed that if the female entrepreneurs' have the beliefs in innovation, they should utilize this beliefs to make their company successful as well.

\section{H4: Innovation Conviction (ICN) has a significant association with Innovation Mindset (IMT)}

\section{H5: Innovation Mindset (IMT) has a significant association with Innovation Creed (ICD)}

\section{H6: Innovation Conviction (ICN) has a significant association with Innovation Creed (ICD)}

As the components of innovation comprised ICN, IMT and ICD, three hypotheses (H4, H5 and H6) were developed to facilitate the researcher in investigating their interrelationships. The researcher believed that only with positive mindset, they will believe. And only through proper beliefs, they will eventually evoke their conviction for success. Therefore, the researcher has the strong feeling that ICN, IMT and ICD are related. 


\section{Result}

This section presents data analysis and results of hypotheses tested in this study. Altogether
120 respondents/samples were finalized for statistical analysis. Table 1 presents the demographic information of the respondents and their business venture.

Table 1: Profiles of respondents

\begin{tabular}{|l|l|c|c|}
\hline No & Demographic Variables & No & Percent \% \\
\hline $\mathbf{1}$ & Gender & 120 & 100 \\
\hline $\mathbf{2}$ & Female & & \\
& Races & 40 & 33.33 \\
& Malay & 40 & 33.33 \\
& Chinese & 40 & 33.33 \\
\hline $\mathbf{3}$ & Indian & & \\
& Years in Business Venture & 4 & 3.3 \\
& Below 1 year & 40 & 33.3 \\
& 1-2 years & 36 & 30.0 \\
& 2-5 years & 40 & 33.3 \\
\hline $\mathbf{4}$ & Above 5 years & & \\
& Btaff Turnover & 66 & 55.0 \\
& 5-10w 5\% & 34 & 28.3 \\
& Above 10\% & 20 & 16.7 \\
\hline $\mathbf{5}$ & Hours spend daily to manage & & \\
& Below 5 hours & 6 & 5.0 \\
& 5-8 hours & 40 & 33.33 \\
& 8-10 hours & 56 & 46.7 \\
& Above 10 hours & 18 & 15.0 \\
\hline $\mathbf{6}$ & Business field & & \\
& Food and Beverage & 44 & 36.7 \\
& Fashion and Boutique & 34 & 28.3 \\
& Tele-communication & 12 & 10.0 \\
& Grocery & 4 & 8.3 \\
& Self employed (operated business from & & 3.3 \\
& home) & & 16 \\
& Other & & \\
\hline
\end{tabular}

Descriptive Statistics and Reliability Analysis

Descriptive statistics (mean and standard deviations) are presented in Table 2 . Reliability test was conducted to all the items by measuring the Cronbach's alpha value. As shows in table 2 , the reliability of IMT $(0.785)$,
ICD (0.843) and NFA (0.791) are all above 0.7, except ICN (0.637). However, Nunnally (1975; 1978) also noted that the reliability estimated of 0.50 to 0.60 can be considered as sufficient for basic research. Hence, all the research variables are deemed fit for further statistical analysis and hypothesis testing. 
Table 2: Reliability Analysis

\begin{tabular}{|l|c|c|c|c|}
\hline \multicolumn{1}{|c|}{ Variables } & Items & Mean & Std. Dev. & Cronbach's Alpha \\
\hline $\begin{array}{l}\text { Innovation Conviction } \\
\text { (ICN) }\end{array}$ & 4 & 4.025 & 0.518 & 0.637 \\
\hline Innovation Mindset (IMT) & 4 & 4.010 & 0.590 & 0.785 \\
\hline Innovation Creed (ICD) & 4 & 3.915 & 0.663 & 0.843 \\
\hline $\begin{array}{l}\text { Need for Achievement } \\
\text { (NFA) }\end{array}$ & 5 & 3.968 & 0.676 & 0.791 \\
\hline
\end{tabular}

\section{Normality Test}

Normality test was conducted on the research variables. Table 3 presents the test results.

Table 3: Tests for Normality

\begin{tabular}{|l|r|r|r|}
\hline \multirow{2}{*}{ Items } & \multicolumn{3}{|c|}{ Kolmogorov-Smirnov test } \\
\cline { 2 - 4 } & Statistic & \multicolumn{1}{c|}{$\mathrm{df}$} & \multicolumn{1}{c|}{ Sig. } \\
\hline IMT & .151 & 120 & .000 \\
ICN & .126 & 120 & .000 \\
ICD & .168 & 120 & .000 \\
NFA & .151 & 120 & .000 \\
\hline
\end{tabular}

The result shows that the research variables (with the population of 120) have p-value $<0.001$ for the K-S test, which indicate that the distributions of the variables are significantly different from a normal distribution. Hence, non-parametric statistical analysis techniques were selected to test the hypotheses of this research, i.e. Spearman Correlation (Rho).

\section{Hypothesis Testing}

The study aims to investigate the associations between the independent variables (IMT, ICN, ICD) and the dependent variable (NFA) of the study; among female entrepreneurs in Malaysia. Table 4 presents the summary of correlation analysis between the independent and dependent variables.

Table 4: Summary of Hypothesis Testing

\begin{tabular}{|c|c|c|c|c|}
\hline Hypothesis & Hypothesis & $\begin{array}{c}\text { Spearman's } \\
\text { Rho* }\end{array}$ & p-value & Result \\
\hline H1 & ICN $\rightarrow$ NFA & $.446^{* *}$ & $<0.001$ & Significant \\
\hline H2 & IMT $\rightarrow$ NFA & .470 & $<0.001$ & Significant \\
\hline H3 & ICD $\rightarrow$ NFA & .525 & $<0.001$ & Significant \\
\hline H4 & ICN $\rightarrow$ IMT & .649 & $<0.001$ & Significant \\
\hline H5 & IMT $\rightarrow$ ICD & .599 & $<0.001$ & Significant \\
\hline H6 & ICN $\rightarrow$ ICD & $.673^{*}$ & $<0.001$ & Significant \\
\hline
\end{tabular}

* Highest correlation among research hypotheses

** Lowest correlation among research hypotheses 
H1: Innovation Conviction (ICN) has a significant association with Need for Achievement (NFA)

This hypothesis is tested and the Spearman Rho correlation coefficient value is 0.446 with p-value $<0.001$, significant at $5 \%$ significance level. $\mathrm{H} 1$ is supported and the study concludes that there is a significant moderate positive correlation between innovation conviction (ICN) and the need for achievement (NFA) among female entrepreneurs in Malaysia. This hypothesis yield the lowest correlation coefficient among all the hypotheses tested in this study.

H2: Innovation Mindset (IMT) has a significant association with Need for Achievement (NFA)

The Spearman Rho's correlation between innovation mindset (IMT) and the need for achievement (NFA) is 0.470 and $p<0.001$. The study supports $\mathrm{H} 2$ and concludes that there is a significant moderate positive correlation between innovation mindset (IMT) and the need for achievement (NFA) among female entrepreneurs in Malaysia.

H3: Innovation Creed (ICD) has a significant association with Need for Achievement (NFA)

The Spearman Rho value for these two variables is 0.525 with $p$-value $<0.001$. The study supports $\mathrm{H} 3$ and concludes that there is a significant moderate correlation between ICD and NFA among female entrepreneurs in Malaysia.

H4: Innovation Conviction (ICN) has a significant association with Innovation Mindset (IMT)

A Spearman Rho's correlation analysis reveals Rho value of 0.649 with p-value $<0.001$. $\mathrm{H} 4$ is hence supported. The study concludes that ICN has a significant positive and moderately high correlation with the IMT.

H5: Innovation Mindset (IMT) has a significant association with Innovation Creed (ICD)

The correlation coefficient on the hypothesis H5 revealed a Spearman Rho value of 0.599 with $\mathrm{p}$ value $<0.001$. Thus the result reinforces hypothesis $\mathrm{H} 5$ that innovation mindset (IMT) is significantly (positive) associated with innovation creed (ICD). Based on these results, the success of innovation is found to be heavily related with IMT and ICD.

H6: Innovation Conviction (ICN) has a significant association with Innovation Creed (ICD)

Spearman Rho's value for this hypothesis is 0.673 with p-value less than 0.001 . Hypothesis H6 is hence supported and the study concludes that there is a significant high positive correlation between ICN and the ICD. Correlation between ICN and ICD is found to be the highest among all the hypotheses tested in this study.

\section{Discussion and Conclusion}

The study examines factors that are association to the need for achievement among female entrepreneurs in Malaysia, particularly focusing on the dimension of innovation. Research data were collected from female entrepreneurs represented by the major races in Malaysia using purposive sampling, which include Malay, Chinese and Indian. Each race was represented equally in this study. Finding shows positive correlation between innovation mindset (IMT), innovation conviction (ICN) and innovation creed (ICD) to the need for achievement (NFA) among female entrepreneurs in Malaysia.

The mindset, conviction and creed of entrepreneurs affect the individual's perception of innovation and drive her towards innovation. In addition, from feedback received from respondents, most tend to think that innovation and experience are both equally important aspects for a successful venture. The respondents participated in this study indicated that their experience drove them towards venturing into new business. Interviewed respondents also indicated that they feel innovation is more important for female entrepreneurs than for male entrepreneurs to succeed in their business ventures, because they feel women entrepreneurs need to be more competitive and offer differentiated products to be accepted in the market. 
Innovation is often cited as a vital factor for business sustenance. Attitude towards innovation cannot be handed down easily without overcoming challenges posed by subordinates who often oppose change that comes from innovation. Entrepreneurs also face challenges in encouraging their workers and subordinates to innovate new ideas, products and services. Female entrepreneurs in Malaysia realize that they need to take the lead and motivate their workers and subordinates consistently towards adopting innovation culture in the workplace.

This study with empirical evidence, suggests that innovation is important for success in business venture. To make innovation a part of the business practice, business owners need to develop the right attitude, conviction and creed in practicing the innovative mind. Attitude toward innovation seems to be the most important determinant that put together all other aspects of innovation in place for a business venture. Entrepreneurs with the right attitude towards innovation, coupled with motivation to put their innovation into practice, and pass down this zeal to their subordinates and workers would achieve success in their business ventures.

The findings of this study are significant in highlighting the importance of the innovative conviction, creed and mindset in affecting the need for achievement for female entrepreneurs in Malaysia. The findings add new information and insights to the current limited body of literatures on women entrepreneurship in Malaysia. It helps to further understand women entrepreneurs as a unique segment of entrepreneurs, and on how they think and act in relation to innovation in their business practices.

\section{Limitations and Future Research}

This study focused on Malaysian female entrepreneurs and was limited in its data collection. As this is an ongoing study, most data collected and presented in this paper came through respondents from the Southern Region of Malaysia, i.e. Melaka and Johor states. Future study could expand data collection to more states in Malaysia, including East
Malaysian states. Other success factors for female entrepreneurs should also be studies, such as risk-taking behaviour, self-motivation, self-confident, experience in business and the need for survival in business. Although innovation is regarded as a critical factor to succeed, other factors should not be neglected; they could also be examined empirically to discover their effects on the success of businesses run by female entrepreneurs in Malaysia and other developing countries.

The effect of internet to entrepreneurship should also be studied especially as this would facilitate innovation implementation in organizations. According to recent works (Tan and Eze, 2008; Tan et. al., 2009a; Tan et. al., $2009 \mathrm{~b})$, e-commerce and e-business are still largely unpopular among SMEs in Malaysia. While most female entrepreneurs are involved in SMEs, it would be worth studying the effect of ICT to the success of female entrepreneurs.

\section{References}

Acs, Z. (2006) "How Is Entrepreneurship Good for Economic Growth? Innovations: Technology, Governance". Globalization. 1(1): 97-107.

Arfken, Deborah E., Bellar, Stephanie L., and Helms, Marilyn M. (2004), "The Ultimate Glass Ceiling Revisited: The Presence of Women on Corporate Boards", Journal of Business Ethics, 50(2), 177-186

Audretsch, D.B. and Thurik, R. (2001) "What is new about the new economy: sources of growth in the managed and entrepreneurial economies", Industrial and Corporate Change. 10(1): 25-48.

Audretsch, D.B., Keilbach, M.C., and Lehmann, E.E. (2006) Entrepreneurship and Economic Growth. Oxford University Press: Oxford.

Baumol, W.J. (1993), "Formal entrepreneurship theory in economics: existence and bounds", Journal of Business Venturing, 8, 197-210. 
Birch,D. (1987) "An Analysis of Small Business Size and Rate of Discontinuance", Journal of Small Business Management, 7(4), 1-7.

Brambilla, I (2009), "Multinationals, Technology and the Introduction of Varieties of Goods", Journal of International Economics, 79, 89-101

Carland, J.W., and Carland, J.C. (1992). "Managers, Small Business Owners and Entrepreneurs, The Cognitive Diomension". Journal of Business and Entrepreneurship. 4(2), 55-62

Casson, Mark C. (1982a) The Entrepreneur: An Economic Theory. Second edition. Oxford: Martin Robertson

Casson, Mark C. (1982b), The Entrepreneur: An Economic Theory, Barnes \& Noble Books, Totowa, NJ

Catalyst (2002), "2002 Catalyst Census of Women Corporate Officers and Top Wage Earners in the Fortune 500", Catalyst, New York, NY:Catalyst, Inc

Davis, Susan E.M. and Long, Dinah D. (1999), "Women Entrepreneurs: What do they need?". Business and economic Review, 45 (4), 25-26

Heunks, J, (1998) "Innovation, Creativity and Success", Journal of Small Business Economics, 10(3), 263-272

Hisrich, R. D. and Brush, C.G. (1986). The Woman Entrepreneur: Starting, Managing, and Financing a Successful New Business. Lexington Books, Lexington, MA.

Hisrich, R. D. and Peters, M. P. (2002). Entrepreneurship, McGraw-Hill: NJ

Hornaday, Jonh A., and Charles S.Bunker, (1970) "The Nature of the Entrepreneur". Personnel Psychology, 23(1), 47-54.

Hummels D. and V. Lugovskyy (2005), "Trade in Ideal Varieties: Theory and Evidence", NBER Working Paper No 11828, Krannert School of Management, Purdue University [Online], [Retrieved on April 1 $1^{\text {st }}$ 2010], http://www.nber.org/papers/w11828.pdf
Kangasharju, A. (2000). "Growth of the smallest: Determinants of small firm growth during strong macroeconomic fluctuations", International Small Business Journal, 19(1), 2843.

Kiyonari, T., Nakamura, S., and Hirao, K. (1971) Bencha bijinesu (Venture Business), NihonKeizai Shimbun Sha.

Kuczmarski, Thomas D,. (1996). Innovation: Leadership Strategies for the competitive edge. NTC Business Books: Lincolnwood.

Langowitz, NS \& Morgan, C (2003), 'Women entrepreneurs', in JE Butler (ed), New Perspectives on Women Entrepreneurs, Information Age Publishing Inc., America, 101119.

Lee, J (1996), 'The motivation of women entrepreneurs in Singapore', Women in Management Review, 11(2), 18-29.

March J. G. (1991). "Exploration and exploitation in organizational learning", Organization Science, 2(1), 71-87.

McClelland, E, Swail, J, Bell, J \& Ibbotson, P (2005), "Following the pathway of Female entrepreneurs: A six-country investigation", International Journal of Entrepreneurial Behavior \& Research, 11(2), 84-107.

Moore, D. and Buttner, E.H. (1997). Women Entrepreneurs: Moving Beyond The Glass Ceiling. Sage Publications: Thousand Oaks, CA.

Normah Mohd, Aris. (2006). "SMEs: Building Blocks For Economic Growth. National Statistics Conference", Department of Statistics, Malaysia, 4-5 September 2006. [Online], [Retrieved March 8th, 2010], http :/www.digitalibrary.my/dmdocuments/m alaysiakini/266_22Hjh_Normah.pdf. .

Nunnally, J.C. (1975). Introduction to Statistics for psychology and education. McGraw-Hill: New York:

Nunnally, J. C. (1978). Psychometric theory ( $2^{\text {nd }}$ ed.). McGraw-Hill: New York 
Porter, M.E. (1985). Competitive Advantage: Creating and Sustaining Superior Performance. The Free Press: New York

Ronstadt, R (1988), 'The Corridor Principle', Journal of Business Venturing, 1(3), 31-40.

Sekaran, U (2002). Research Methods for Business. $4^{\text {th }}$ Edition.. John Wiley: New York, NY

Starr, J. and Yudkin, M (1996). Women Entrepreneurs: A Review of Current Research. Wellesley. MA, Center for Research on Women.

Shefsky, L. (1994). Entrepreneurs Are Made not Born: Secrets from 200 Successful Entrepreneurs. McGraw-Hill: New York, NY

Silver, A D.(1983). The entrepreneurial life: How to go for it and get it. John Wiley: New York, NY

Tan K. S. and Eze U. C. (2008). "An Empirical Study of Internet-Based ICT Adoption Among Malaysian SMEs", Proceeding of 10th International Business Information Management Association (IBIMA), 978-09821489-2-1, 30 June-2 July 2008, Kuala Lumpur, Malaysia, 292-302.

Tan K. S., Chong S. C. and Eze, U.C. (2009a). "Factors Influencing Internet-based ICT Adoption among Malaysian SMEs",
International Journal of Management \& Enterprise Development", 6(4), 397-418.

Tan, K. S., Chong S. C., Lin, B. and Eze, U. C. (2009b). "Internet-Based ICT Adoption: Evidence from Malaysian SMEs", Industrial Management \& Data Systems, 109(2), 224-244.

Verheul,I., A. Van, Stel and A.R. Thurik. (2006). Explaining Female and Male Entrepreneuship across 29 countries. SCALES-paper N200403, working paper series of EIM Business and Policy Research [Online], [Retrieved April 22, 2010], http://www.ondernemerschap.nl/pdfez/N200403.pdf.

Wennekers, Sander. (2006), “Entrepreneurship at country level, Economic and non-economic determinants" Scales Research Reports R200602, EIM Business and Policy Research [Online], [Retrieved April 23, 2010], http://www.entrepreneurship-sme.eu/pdfez/R200602.pdf

Wennekers, S. and Thurik, R. (1999) "Linking Entrepreneurship and Economic Growth", Small Business Economics. 13(1): 27-55.

Wickham, P.A. (2004), Strategic Entrepreneurship, 3rd ed., Pearson Education Limited, Harlow.

Zimerer, T. W. and Scarborough, N. M. (2002). Essentials of Entrepreneurship and Small Business Management. NJ: Pearson Education 


\section{Appendix A}

Measures of NFA, ICN, IMT and ICD were adapted from Kurzmarski (1996)

NFA (5 items)

1) Successful business women are able to create profits and increase profits on yearly basis.

2) Successful business women are able to manage and maintain the manpower.

3) Successful business women are able to allocate time between business and personal life.

4) Successful business women are able to operate business and maintain in the long-term.

5) Successful business women have a well plan for expanding the business.

ICN (4 items)

1) Personally, successful businesswomen are aware of several other industries that have grown through innovation.

2) Successful businesswomen are aware that profits margins of any existing product lines will continue to fall because of competition.

3) Successful businesswomen are notice that at least one of their key competitors has successfully increased its competitive advantage through implementation of innovation.

4) Successful businesswomen are capable at reducing cost structures, streamlined work force and reengineered processes.

IMT (4 items)

1) Successful businesswomen will use innovation and launch new products that accelerate their company's value.

2) Successful businesswomen will conduct consumer research studies prior to idea generation for proper problems and needs identification.

3) Successful businesswomen listen to others within the organization that talks about her positive, enthusiastic, supportive and "can-do" attitude towards innovation

4) Successful businesswomen make an innovation as an attractive career for hers employees to pursue.

ICD (4 items)

1) Successful business women believed that innovative new products and services are integral to company's future success

2) Successful businesswomen believed that internal innovation will yield greater returns

3) Successful businesswomen believed that innovation should be one of the top five priorities and remain on "to-do" list

4) Successful businesswomen believed that an effective innovation mindset can motivate employees

to perform better and more productive 